\title{
A study of the hydraulic parameters and ecological significance of braided rivers under flow variations
}

\author{
Wang $\mathrm{Hao}^{1}$, Hong $\mathrm{Li}^{2}$, Lihua $\mathrm{You}^{2}$, Lu Yun${ }^{1}$, Zaixiang Zhu ${ }^{1}$, and Yong $\mathrm{Li}^{1}$ \\ ${ }^{1}$ Sichuan University State Key Laboratory of Hydraulics and Mountain River Engineering \\ ${ }^{2}$ Sichuan Province Zipingpu Development Co Ltd Chengdu Sichuan China
}

July 16, 2021

\begin{abstract}
Numerical modeling of braided channels showed no significant differences in the number of cross-sectional branches between different water periods in the middle reaches of the Yarlung Tsangpo River. During most of the year (wet, normal and dry periods), flow velocities in the higher-branching (HB) channels were significantly lower than in the other two branching categories, while the overall distribution of depth in the higher-branching channels maintained a high degree of consistency with the moderate-branching channels (MB), which partly explains why the HB channels are important habitats for fish spawning, nursery and baiting (lower flow velocity distribution with a wider range of depth). Based on the examination of the water surface width, the water surface width may not be a limiting factor for fish habitat within braided rivers. Simulation of the hydrodynamic parameters of the fish-spawning grounds revealed that the average cross-sectional flow velocity and water depth fluctuated the least at different flows during the fish-spawning period for the HB channels. By counting the hydraulic parameters of the spawning grounds during the spawning period, it can be seen that the most preferred flow velocity for fish in the braided river in the study section was $0.1-0.4 \mathrm{~m} / \mathrm{s}$, and the water depth was $0-1.2 \mathrm{~m}$. This article analyses the characteristics of the hydraulic parameters of the braided river and provides theoretical support for the restoration of fish habitats in braided rivers.
\end{abstract}

\section{Hosted file}

Article.docx available at https://authorea.com/users/425944/articles/530625-a-study-of-thehydraulic-parameters-and-ecological-significance-of-braided-rivers-under-flow-variations

\section{Hosted file}

Figures.docx available at https://authorea.com/users/425944/articles/530625-a-study-of-thehydraulic-parameters-and-ecological-significance-of-braided-rivers-under-flow-variations 